\title{
$1.5 \mathrm{Si}-19 \mathrm{Cr}-5 \mathrm{Ni}-2.7 \mathrm{Mo}$ 系 2 相ステンレス鋼の 耐食性に及ぼす窒素添加の影響
}

\author{
藤原 和 雄 $*$, 泊里治 夫** \\ * 株式会社神戸製鋼所材料研究所（現株式会社コベルコ科研） \\ ** 株式会社神戸製鋼所材料研究所
}

\author{
Effect of Nitrogen Addition on Corrosion Resistance of \\ 1.5Si-19Cr-5Ni-2.7Mo Duplex Stainless Steel \\ Kazuo Fujiwara* and Haruo Tomari** \\ *Kobe Steel Ltd. (Presently: KOBELCO Research Institute Inc.) \\ **Kobe Steel Ltd.
}

\begin{abstract}
In order to improve the corrosion resistance of ASTM A $669(1.5 \mathrm{Si}-19 \mathrm{Cr}-5 \mathrm{Ni}-2.7 \mathrm{Mo}$ duplex stainless steel), the effect of nitrogen addition of about 0.1 mass $\%$ were studied. The resistances of base metal and welded joints of duplex stainless steels with and without nitrogen to crevice corrosion and stress corrosion cracking in chloride environments were evaluated in comparison to those of SUS 304 and $316 \mathrm{~L}$ as reference materials. The effects of nitrogen addition, restraint stress and filler metal on microstructure, especially formation of austenite phase in the welding heat affected zone were also investigated in detail. The addition of nitrogen was clarified to improve extremely the corrosion resistance and to accelerate the precipitation of austenite phase in the welding heat affected zone of the duplex stainless steel. Although austenite free zone, which might cause intergranular attack, tended to form in the heat affected zone by welding under restraint stress even in nitrogen containing steel, the selection of proper filler wires, such as $0.01 \mathrm{C}-23 \mathrm{Cr}-7 \mathrm{Ni}-3 \mathrm{Mo}-0.14 \mathrm{Nsteel}$, made it possible to produce the sound welded joint with adequate amount of austenite phase to prevent the intergranular attack.
\end{abstract}

Key words: duplex stainless steel, nitrogen, corrosion resistance, welding HAZ, austenite free zone, restraint stress, intergranular attack.

\section{1. 緒 言}

ASTM A 669 (Seamless Ferritic-Austenitic Alloy Steel Tubes) に規定された 2 相ステンレス鋼 $(1.5 \mathrm{Si}-$ $19 \mathrm{Cr}-5 \mathrm{Ni}-2.7 \mathrm{Mo}$ 鋼) は, 元来 SUS 304 や 316 など のオーステナイト系ステンレス鋼の久点である応力腐食 割れ (以後 SCC と略記する) に対する抵抗性を改善する ために開発された鋼種で, 比較的低濃度の塩化物環境下 で使用される熱交換器の伝熱管材料などとしてこれまで に多数の使用例が報告されている1)。しかしながら, 最 近 ASTM では, 0.05 0.10 mass\%の のを添加した鋼種

* T651 神戸市中央区脇浜町 1-2-3 (1-2-3, Wakinohama-cho, Chuo-ku, Kobe, 651 Japan)

** 干651 神戸市中央区脇浜町 1-3-18 (1-3-18, Wakinohama-cho, Chuo-ku, Kobe, 651 Japan)
が A 789/A 789 M-87a S 31500 として規定されている。 筆者らはこのA 669 鋼の塩化物に対する耐食性が必ず しも十分でなく，特に溶接熱影響部 (HAZ) で生成する フェライト $(\alpha)$ 単相部の耐食性劣化を生じる場合がある が, これに窒素 $(\mathrm{N})$ を添加することにより母材の耐食 性はもちろん溶接熱影響部の耐食性が著しく改善される ことを見出し，さらにその改善機構について溶接熱影響 部の顕微鏡組織変化との関連で考察を加えたので以下に 報告する。

\section{2. 実験方法}

\section{1 供試材料}

供試材料の化学成分を Table 1 亿示す。No. 1 は従来

の A 669 飞相当するもの, No. 2 はこれのN含有量を 
Table 1 Chemical compositions of steels tested.

\begin{tabular}{|c|c|c|c|c|c|c|c|}
\hline \multirow{2}{*}{ No. } & \multirow{2}{*}{ Steels } & \multicolumn{6}{|c|}{ Chemical Compositions (mass\%) } \\
\cline { 3 - 8 } & & $\mathrm{C}$ & $\mathrm{Si}$ & $\mathrm{Cr}$ & $\mathrm{Ni}$ & Mo & $\mathrm{N}$ \\
\hline 1 & $\mathrm{~A} 669$ & 0.013 & 1.57 & 18.3 & 5.05 & 2.71 & 0.02 \\
\hline 2 & Mod. A669 & 0.015 & 1.64 & 18.7 & 5.10 & 2.76 & 0.11 \\
\hline 3 & SUS304 & 0.064 & 0.42 & 17.8 & 8.57 & 0.11 & - \\
\hline 4 & SUS316L & 0.012 & 0.70 & 17.5 & 12.15 & 2.12 & - \\
\hline
\end{tabular}

0.1 mass\% に高めたもので, いずれも真空高周波炉によ り $150 \mathrm{~kg}$ の鋼塊を溶製し，その一部は熱間鍛造，熱間圧 延により $4^{\mathrm{t}} \times 150^{\mathrm{w}} \times \mathrm{L}^{1} \mathrm{~mm}$ の鋼板とした後 $1050^{\circ} \mathrm{C} \times 30$ $\min \rightarrow$ 水冷の溶体化熱処理を施した。また，鋼塊の残部 については熱間鍛造によって $155{ }^{\phi} \times \mathrm{L}^{1} \mathrm{~mm}$ のブルーム とした後, 熱間押出一冷間抽伸法により, 外径 $19 \mathrm{~mm}$, 肉 厚 $1.6 \mathrm{~mm}$ の継目無し鋼管を製作した。鋼種 No. 3 及 び 4 の SUS 304 及び SUS 316 L は, 耐食性試験のため の比較材として用いたもので, 市販の圧延鋼板 (板厚 21 $\mathrm{mm})$ を供試した。

\section{2 腐食試験方法}

本研究で実施した腐食試験の試験条件の概略を Table 2 にまとめて示す。

Table 2 Summary of corrosion test conditions.

\begin{tabular}{|c|c|c|c|}
\hline Materials & Test & Method & Environ. Condition \\
\hline \multirow{3}{*}{$\begin{array}{l}\text { Base } \\
\text { Metal }\end{array}$} & $\begin{array}{l}\text { Crevice } \\
\text { Corrosion }\end{array}$ & $\begin{array}{c}\text { Macro-cell } \\
\text { System }\end{array}$ & $\begin{array}{l}\mathrm{Cl}^{-}: 0.01-2 \text { mass } \% \\
\text { Temp.:20 } 80^{\circ} \mathrm{C}\end{array}$ \\
\hline & \multirow[t]{2}{*}{$\mathrm{SCC}$} & C-ring & $\begin{array}{l}\mathrm{Cl}^{-}: 0.01-2 \text { mass } \% \\
\text { Temp. } 80 \& 150^{\circ} \mathrm{C}\end{array}$ \\
\hline & & $U$-bend & Boiling $35 \% \mathrm{MgCl}_{2}$ \\
\hline \multirow{2}{*}{$\begin{array}{c}\text { Welded } \\
\text { Joint }\end{array}$} & \multirow{2}{*}{ SCC } & U-bend & $\begin{array}{l}\mathrm{Cl}^{-}: 2 \text { mass } \% \\
\text { Temp. }: 120^{\circ} \mathrm{C}\end{array}$ \\
\hline & & Spot-welding & $\begin{array}{l}\mathrm{Cl}^{-}: 0.01-2 \text { mass } \% \\
\text { Temp.: } 80^{\circ} \mathrm{C}\end{array}$ \\
\hline
\end{tabular}

\subsection{1 隙間腐食試験}

ステンレス鋼の塩化物環境下における実験室的隙間腐 食試験方法に関しては, 種々の方法が提案されている が2),3), 本研究では, 実使用環境に近い条件下で耐食限 界を求めるため, マクロセル方式による電気化学的手 法4）を採用した。この方式による実験装置の概略を模式 的に Fig. 1 亿示す。各供試材料より短冊状試験片 $\left(2^{\mathrm{t}} \times\right.$ $22^{\mathrm{w}} \times 40^{1} \mathrm{~mm}$ ) を切り出し，エメリー紙で \#400 まで湿式 研磨し,リード線をスポット溶接した後その両面に 16 個の溝を付けた外径 $20 \mathrm{~mm}$ ，内径 $8 \mathrm{~mm}$ の PTFE ワッ シャーを取り付けたもの5)を隚間腐食電極（マクロア） 一ド)とし，これを Table 2 に示した所定の組成 (イオン 交換水と $\mathrm{NaCl}$ で $\mathrm{Cl}^{-}$濃度を調整) および温度の試験液 中に浸漬する。一方, 表面積約 $2,400 \mathrm{~cm}^{2}$ のSUS $316 \mathrm{~L}$ 鋼板にスポット溶接したものをマクロカソードとして

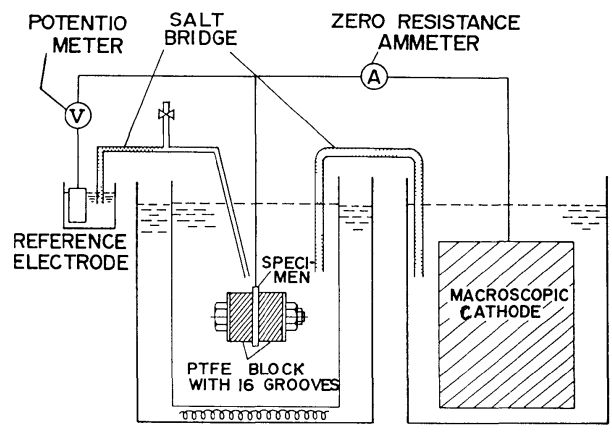

Fig. 1 Schematic presentation of apparatus for crevice corrosion test by macro-cell system.

(マクロアノード/マクロカソードの面積比は約 1:2000 となる), 常温の同一組成の 溶液中に浸漬して両液を塩 橋を介して液絡するとともに，マクロアノードとマクロ カソードの間に流れる短絡電流の経時変化を無抵抗電流 計で測定する。溶液は, いずれも大気開放状態で測定し た。一定期間 (30 日) 浸漬後試験片を取り出し, マクロ アノード上で隍間腐食を生じた部分の面積を測定して， 短絡電流值をこの面積で除することによって隙間腐食進 展速度 $(\mathrm{mm} / \mathrm{y})$ を算出した。この方式によりクーラーや コンデンサーなどの冷却水を用いる熱交換器の伝熱管な どに生じる吵間腐食の進展速度を定量的に把握しうるも のと考えられる ${ }^{\mathrm{b}}$ 。

\subsection{2 応力腐食割れ試験}

SCC 試験は母材及び溶接部の両者について行った。

（1）母材：SCC 試験は C リング法及びUベンド法 により行った。C リング試験片は鋼種 No. 1 及び 2 に ついては継目無し鋼管より, 鋼種 No. 3 及び 4 について は圧延鋼板より，19 $\phi \times 1.6^{\mathrm{t}} \times 16^{\mathrm{w}} \mathrm{mm}$ の試験片を切り 出し, ボルト・ナットを用いて常温でその材料の $0.2 \%$ 耐力に相当する引張応力を付加した状態で, Table 2 に 示した条件の食塩水中に 60 日間浸漬した。浸漬後の試 験片の断面を光学顕微鏡で観察することにより SCC 感 受性を評価した。U ベンド試験片は鋼板より $2^{\mathrm{t}} \times 15^{\mathrm{w}} \times$ $65^{1} \mathrm{~mm}$ の試験片を切り出し, 半径 $5 \mathrm{~mm}$ のローラー/ポ ンチを用いてU曲げしボルト・ナットで脚部が平行にな るまで締め付けて応力を付加した状態で沸騰 35 mass\% $\mathrm{MgCl}_{2}$ 水溶液中に 24 時間浸漬した。浸漬後の試験片 は，断面を光学顕微鏡で観察して最大 SCC 深さを測定 した。

（2）溶接部：溶接部の SCC 試験はUベンド法及び スポット溶接法7)により行った。U ベンド試験は鋼種 No. 1 及び 2 について板厚 $4 \mathrm{~mm}$ の鋼板を GTAW 法に てなめ付け溶接した後, $2^{\mathrm{t}} \times 15^{\mathrm{w}} \times 65^{\mathrm{I}} \mathrm{mm}$ の試験片を切 り出し, 半径 $5 \mathrm{~mm}$ のローラー/ポンチを用いて 溶着部 


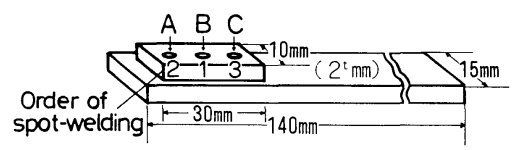

Fig. 2 Geometry of spot-welded test specimen for SCC test.

が中央になるようU曲げし，ボルト・ナットで締め付け て応力を付加した状態で, $120^{\circ} \mathrm{C}$ の 2 mass $\% \mathrm{Cl}^{-}$の食 塩水中に 14 日間浸漬することにより行った。スポット 溶接試験は Fig. 2 飞示すように, 板厚 $2 \mathrm{~mm}$ の 2 枚の 鋼板を再現性チェックのため $\mathrm{B} \rightarrow \mathrm{A} \rightarrow \mathrm{C}$ の順に $10 \mathrm{~mm}$ の間隔で 3 箇所スポット溶接し, そのままの状態で Table 2 に示した条件の食塩水中に 180 日間浸漬すること により行った。評価はいずれの場合も試験片断面の光学 顕微鏡観察により行った。

\section{3 顕微鏡組織観察}

2 相ステンレス鋼の溶接材及び溶接熱サイクル再現熱 処理材は光学顕微鏡にて金属組織を詳細に観察するとと もに, 一部の試験片については EPMA (島津 EPM-810 Q)による線分析により主要成分の分布状況を測定した。 腐食液には村上試薬を使用した。溶接熱サイクル再現熱 処理は溶融部近傍の状況を再現するため, 富士電波工機 （株）製拘束溶接熱サイクル再現装置を用いて， $1350^{\circ} \mathrm{C}$ まで急速加熱しこの温度で 5 秒間保持した後 $\mathrm{Ar}$ ガスを 吹きつけて急速冷却する $\left(1350^{\circ} \mathrm{C}\right.$ から $1000^{\circ} \mathrm{C}$ の冷却速 度約 $\left.160^{\circ} \mathrm{C} / \mathrm{s}\right)$ ことにより行ったが，この場合拘束応力 の影響を検討するため, 冷却中に試験片を拘束した場合 と拘束しない場合との比較を行った。

\section{3. 実験結果及び考察}

\section{1 母材の耐食性}

\subsection{1 耐隙間腐食性}

0.1 mass $\%$ の $\mathrm{Cl}^{-}$イオンを含む $60^{\circ} \mathrm{C}$ の食塩水中に おいてマクロセル方式により吵間腐食電流の経時変化を 測定した結果を Fig. 3 亿示す。SUS 304 及びN無添加 鋼である A 669 は浸漬当初より数 $\mu \mathrm{A}$ の大きな短絡電流 が流れ，その值は浸漬時間に対してほとんど変化しなか った。一方, SUS $316 \mathrm{~L}$ や N添加 2 相ステンレス鋼 (以 後便宜上 Mod. A 669 と略称する) の場合には浸漬当初 は比較的大きな電流が流れたが，浸漬時間とともにとの 值は減少し, 約 10 日間以降では $0.03 \mu \mathrm{A}$ 程度の小さな 值に安定した。30 日間浸漬後の試験片を観察すると, SUS 304 とA 669 には激しい隙間腐食, SUS 316 L と Mod. A 669 には軽微な隚間腐食が認められた。後者の 隌間腐食は浸漬初期の比較的短絡電流值の大きな時期に 生じたものと考兄られ，これらのことはこのマクロセル 方式によって㭞間腐食の進展状況を定量的に把握しらる

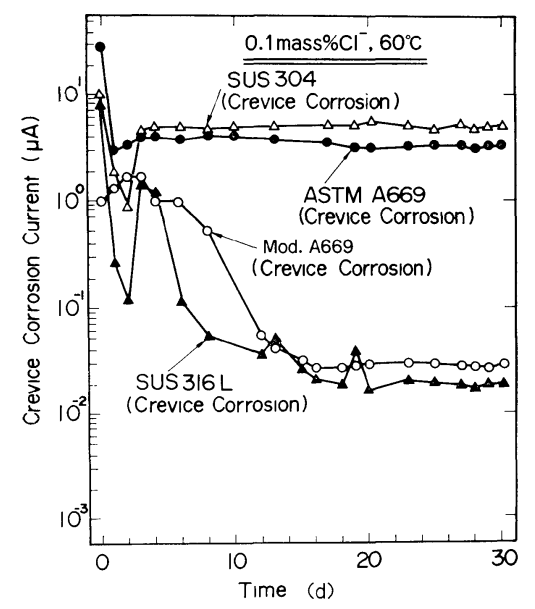

Fig. 3 Time variation of crevice corrosion current of steels in 0.1 mass $\% \mathrm{Cl}^{-}$solution at $60^{\circ} \mathrm{C}$ by macro-cell system.

ことを示唆するものと考光られる。そこで, 以後この短 絡電流を隙間腐食電流と称することにする。

0.1 mass\% の $\mathrm{Cl}^{-}$イオンを含む $20^{\circ} \mathrm{C}$ の食塩水中で 吵間腐食電流の経時変化を測定した結果に执いては，A 669 は浸漬当初より $2 \mu \mathrm{A}$ 程度の隙間腐食電流が継続し て流れたのに対し, Mod. A 669 では浸漬直後より急激 に吵間腐食電流が減少し， $0.01 \mu \mathrm{A}$ 程度の定常值に和ち ついた。30 日間浸漬後の試験片には A 669 の場合隚間 腐食が観察されたが, Mod. A 669 では認められなかっ た。

隙間腐食の進展状況をより定量的に把握するため, 測 定された吵間腐食電流を試験片上の吵間腐食を受けた部 分の面積で除して，隙間腐食進展速度に換算した。この 場合隙間腐食電流值としては定常状態に達した後の值を 採った。この值を各温度の 0.1 mass $\% \mathrm{Cl}^{-}$の食塩水中で 求め, 試験温度に対してプロットした結果をFig. 4 亿示 す。隙間腐食進展速度はいずれの鋼種に扔いても試験温 度の低下とともに減少するが, 肉厚 $1.25 \mathrm{~mm}$ の材料が 10 年間で貫通孔を生じる進展速度,すなわち $0.125 \mathrm{~mm} /$ $\mathrm{y}$ になる条件を一応耐食限界と見なすと， 0.1 mass\% $\mathrm{Cl}^{-}$溶液中では SUS 304 打よび A 669 の耐食限界温度 は $20^{\circ} \mathrm{C}$ 以下, SUS $316 \mathrm{~L}$ 打よび Mod. A 669 注約 60 ${ }^{\circ} \mathrm{C}$ となる。Fig. 5 は同様の手法によって求めた種々の $\mathrm{Cl}^{-}$イオン濃度の食塩水中に抢ける耐食限界条件を図示 したものである。約 $0.1 \mathrm{mass} \%$ のNを添加した 2 相ス テンレス鋼 (Mod. A 669) の耐食限界条件は, SUS 304 やN無添加鋼である A 669 に比較して著しく広がって 招り, SUS $316 \mathrm{~L}$ と同等であった。吵間腐食試験後の試 験片断面の顕微鏡観察による妳間腐食発生状況の一例を Fig. 6 と示す。A 669 ではオーステナイト $(\gamma)$ 相 (白い 


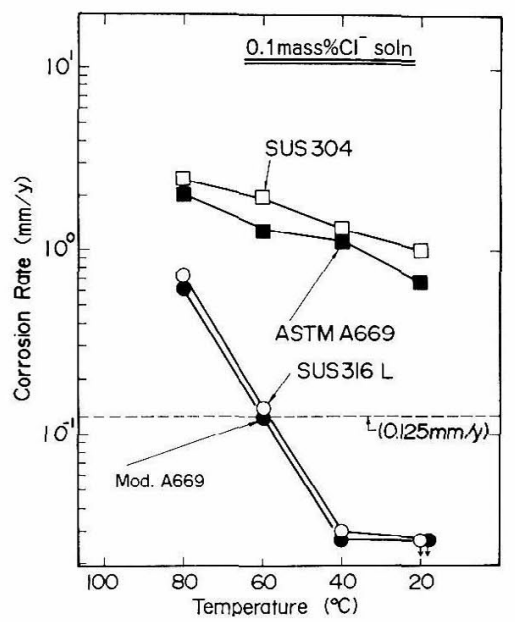

Fig. 4 Effects of solution temperature on crevice corrosion propagation rate in solution containing 0.1 mass $\% \mathrm{Cl}^{-}$by macro-cell system.

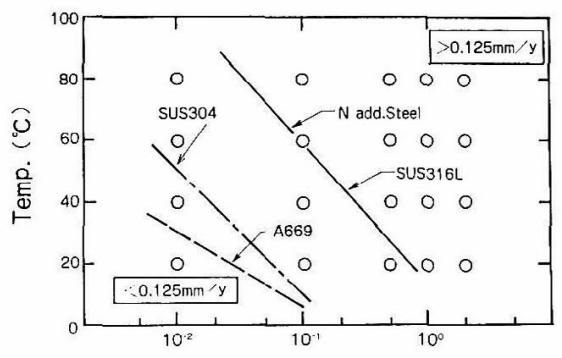

Cl Conc. (mass\%)

Fig. 5 Critical environmental conditions against crevice corrosion as a function of chloride concentration and solution temperature.

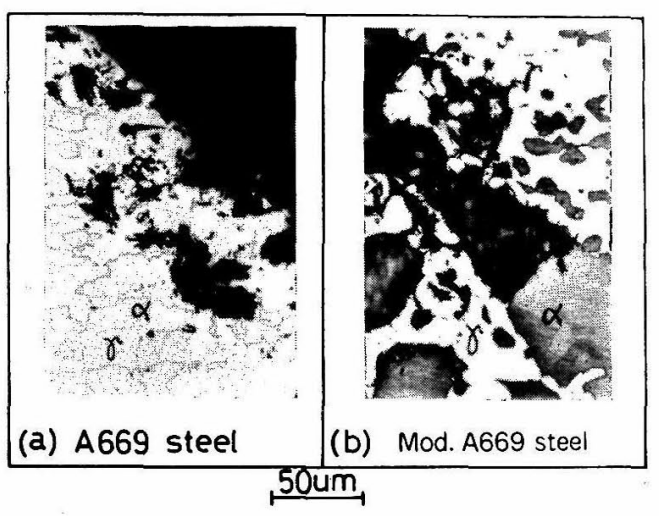

Fig. 6 Microscopic observation of crevice-corroded specimen after tested by macrocell system.

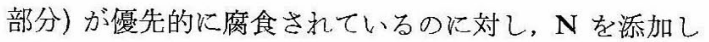
た Mod. A 669 ではフェライト $(\alpha)$ 相 (死色の部分) が 優先的に腐食されている槏相が観察される。

これらのことから，N の添加によって 2 相ステンレス 鋼の耐隙間腐食性が向上するのは $\gamma$ 相中では $\alpha$ 相中に 比べて耐隙間腐食性の向上に有効な $\mathrm{Cr}$ や Mo の含有量 が減少するが， $\gamma$ 生成元素であるNが濃縮することによ って耐食性が相対的に向上するためで㠰ると考えられ る。

\subsection{2 耐応力腐食割れ性}

$\mathrm{Cl}^{-}$イオン濃度の異なる $150^{\circ} \mathrm{C}$ の食塩水中に括ける $\mathrm{C}$ リング法による SCC 試験結果及び沸騰 35 mass\% $\mathrm{MgCl}_{2}$ 溶液中におけるUベンド法による $\mathrm{SCC}$ 試験結果 をまとめて Table 3 に示す。中性の食塩水中ではオース

Table 3 Summary of stress corrosion cracking tests on base metals ( $\mathrm{NaCl}$ solution: $\mathrm{C}$ ring test for 60 days, $\mathrm{MgCl}_{2}$ solution: U-bend test for 24 hours).

\begin{tabular}{|c|c|c|c|c|c|}
\hline \multirow{2}{*}{$\begin{array}{l}\text { Test } \\
\text { Envirion } \\
c / \text { concis } \\
\text { Steels }\end{array}$} & \multicolumn{4}{|c|}{$\begin{array}{l}\text { O:No SCC , X: SCC } \\
150^{\circ} \mathrm{C}, \mathrm{NaCl} \text { solution }\end{array}$} & \multirow{2}{*}{$\begin{array}{c}\text { Boiling } \\
\text { 35mass\% } \% \mathrm{MgCl}_{2} \\
\begin{array}{c}\text { Crack depth } \\
(\mathrm{mm})\end{array}\end{array}$} \\
\hline & 0.01 & 0.1 & 0.5 & 2 & \\
\hline A669 & 0 & 0 & 0 & 0 & 1.8 \\
\hline Mod. A669 & 0 & 0 & 0 & 0 & 0 \\
\hline SUS 304 & $x$ & $x$ & $n$ & . & 00 \\
\hline SUS316L & $x$ & $x$ & $x$ & $x$ & 0.6 \\
\hline
\end{tabular}

テナイト系ステンレス鋼である SUS 304 や 316 L はい ずれの $\mathrm{Cl}^{-}$イン䟴度です $\mathrm{SCC}$ を生したが，2 相ステ ンレス鋼は両者とも SCCを生じなかった。一方, 沸騰 $\mathrm{MgCl}_{2}$ 溶液中では供試したいずれの鋼種も $\mathrm{SCC}$ を発生 したがここでも 2 相ステンレス鋼における $\mathrm{N}$ の耐 $\mathrm{SCC}$ 吽改善効果が認められた。沸騰 $35 \mathrm{mass} \% \mathrm{MgCl}_{2}$ 溶液は非常に厳しい腐食環境であり，このよらな高濃度 $\mathrm{MgCl}_{2}$ 溶液中では 2 相ステンレス鋼といえどもUベン ド法のような高付加応力下で SCC 圭生じることが従来 より知られている8

\section{2 溶接部の耐食性}

\subsection{1 なめ付け溶接部の耐食性}

2 種の 2 相ステンレス鋼板を用いてなめ付け溶接を行 い, $120^{\circ} \mathrm{C}$ の $\mathrm{Cl}^{-} 1.8$ mass \% の食塩水中に执いてUべ ンド法による SCC 試験を行った。試験後の試験片断面 の蹎微鏡観察結果の代表例を Fig. 7 亿示す。A 669 は溶 接 HAZ に粒界型の SCC が認められるが, Mod. A 669 では SCC の発生は認められない [(a), (c)]。顕微鏡組織 を詳細に観察すると [(b), (d)], A 669 の溶接 HAZ では $\alpha$ 結唱粒が著しく粗大化して括り，SCCの認められる部 分の $\alpha$ 粒界には $\gamma$ 相の析出がほとんど認められないが, 


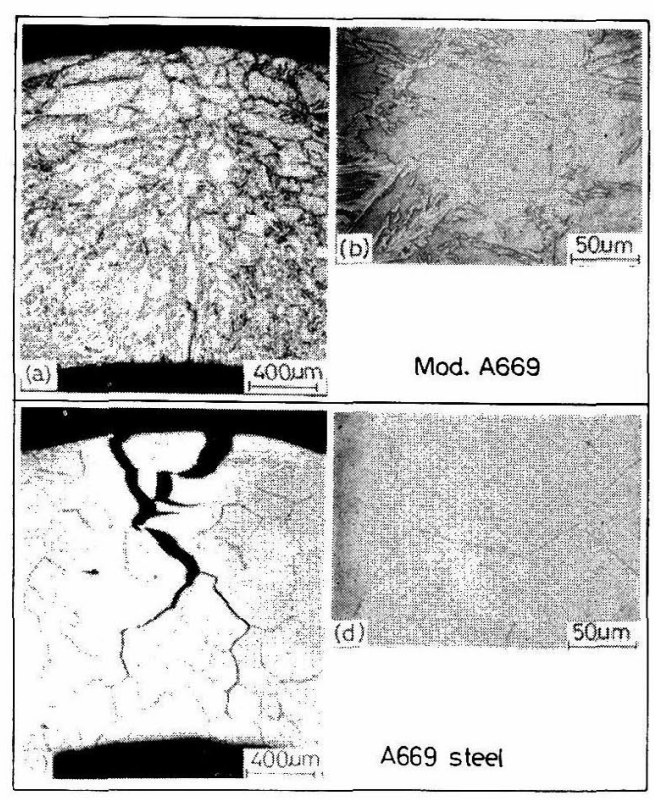

Fig. 7 Cross-sectional microstructure of U-bend specimen machined from non-filler metal welded plate of duplex stainless steels after immersion in $120^{\circ} \mathrm{C}, 3$ mass $\% \mathrm{NaCl}$ solution for 2 weeks.

Mod. A669 の溶接 HAZ では $\alpha$ 結奛粒は粗大化し ているもののその程度は比較的小さく, 結晶粒界には $\gamma$ 相の連続的な析出が観察される。このN添加による粒界 型 SCC の防止機構は次のように解积される。すなわら， $\mathrm{N}$ を添加していない2 相ステンレス鋼に打いては，溶接 熱影響によって高温加熱されると $\alpha$ 単相となるが，その 後の冷却時の冷却速度が大きいため熱力学的に安定な $\gamma$ 相を十分析出させえず，冷却中に $\alpha$ 結晶粒界に Cr の炭 窒化物を析出して $\mathrm{Cr}$ 久乏層の生成による粒界型 $\mathrm{SCC}$ の原因となる。一方， $\gamma$ 生成元素であるNを添加した 2 相ステンレス鋼の場合には, 溶接後の冷却中に $\alpha$ 粒界に 多量の $\gamma$ 相を析出させ, この $\gamma$ 相中での C やNの固溶限 が大きいため $\mathrm{Cr}$ の炭, 窒化物の析出が生じず粒界型の SCC が発生しなかったものと考觉られる。

\subsection{2 スポット溶接部の耐食性と拘束応力の影響}

Fig. 2 に示したよらな 2 枚の鋼板を 3 筒所スポット溶 接した状態で, $\mathrm{Cl}^{-}$イオン濃度の異なる食塩水中に浸漬 乙た後の隚間部分の秙食状況観察結果を Table 4 亿示 す。A 669 は $\mathrm{Cl}^{-}$イオン濃度 0.01 mass\% の場合を除い てすべてのスポット溶接位置で粒界型のSCCを生じた。 一方, $\mathrm{N}$ 添加鋼の場合には, 最初にスポット溶接した $\mathrm{B}$ 部では，粒界型の SCC を生じなかったが，2 番目及び 3 番目に大ポット溶接した $\mathrm{A}$ 部及び $\mathrm{C}$ 部ではいずれの $\mathrm{Cl}^{-}$イオン濃度でも粒界型 $\mathrm{SCC}$ を生じた。各スポット
Table 4 Intergranular attack at the welding HAZ of spot-welded duplex stainless steels in chloride solutions (180 days immersion).

\begin{tabular}{|c|c|c|c|c|}
\hline \multirow{2}{*}{ Steels } & \multirow{2}{*}{$\begin{array}{c}\mathrm{Cl}^{-} \text {conc } \\
\text { (mass\%) }\end{array}$} & \multicolumn{4}{|c|}{ Location of spot-welding } \\
\cline { 2 - 5 } & $\mathrm{A}$ & $\mathrm{B}$ & $\mathrm{C}$ \\
\hline \multirow{3}{*}{ A669 } & 0.01 & $\times$ & 0 & $\times$ \\
\cline { 2 - 5 } & 0.1 & $\times$ & $\times$ & $\times$ \\
\cline { 2 - 5 } & 2 & $\times$ & $\times$ & $\times$ \\
\hline \multirow{2}{*}{ Mod. } & 0.01 & $\times$ & 0 & $\times$ \\
\cline { 2 - 5 } A669 & 0.1 & $\times$ & 0 & $\times$ \\
\cline { 2 - 5 } & 2 & $\times$ & 0 & $\times$ \\
\hline
\end{tabular}

* See Fig.2 (O: NO IGSCC, $x$ : IGSCC)

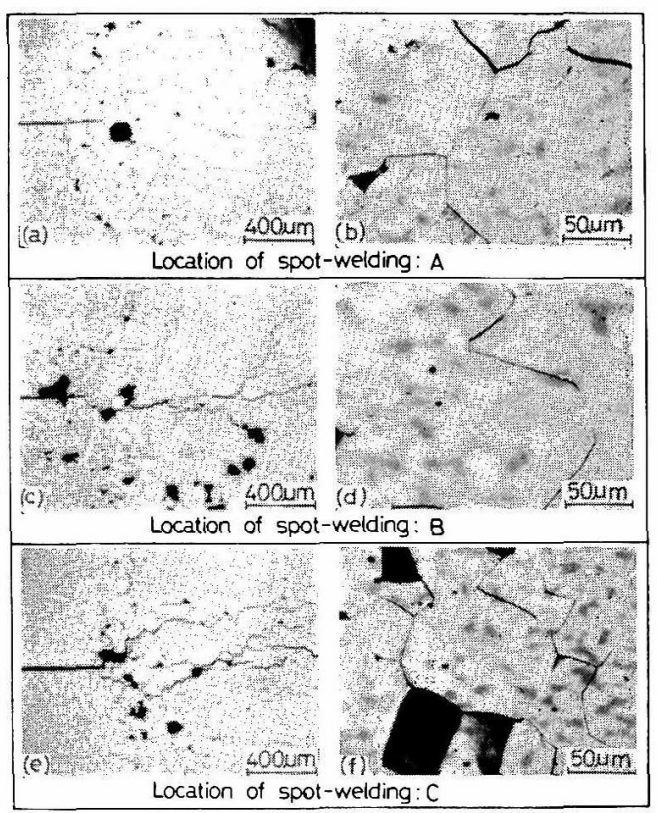

Fig. 8 Micro-structures of HAZ in spot-welded A 669 after immersed in 0.1 mass $\% \mathrm{Cl}^{-}$ solution at $80^{\circ} \mathrm{C}$.

溶接位置での腐食状沉をFig. 8 区び9 亿示す。Fig. 8 に 示す A 669 の場合いずれのスポット溶接位置でも粒界 型の SCC を生じて和り [(a), (c), (e)], また $\alpha$ 粒界への $\gamma$ 相の析出は医とんど認められない [(b), (d), (f)]。この ことはスポット溶接部の EPMA 線分析結果からも確認 された。一方, Fig. 9 に示す Mod. A 669 の場合には, スポット溶接のA部及びC部ではA 669 に比べると蛏 微であるが粒界型の侵食が坐じているが，B 部では粒界 型の侵食は生じていない $[(\mathrm{a}),(\mathrm{c}),(\mathrm{e})]$ 。このことに対応 して，A 部及びC部に䄧ける $\alpha$ 粒界への $\gamma$ 相の析出は 極めて少ないのに対し, B 部では, 連続的な $\gamma$ 相の析出 が認められ [(b), (d), (f)],このことはスポット溶接部の EPMA 線分析結果から確認された。 


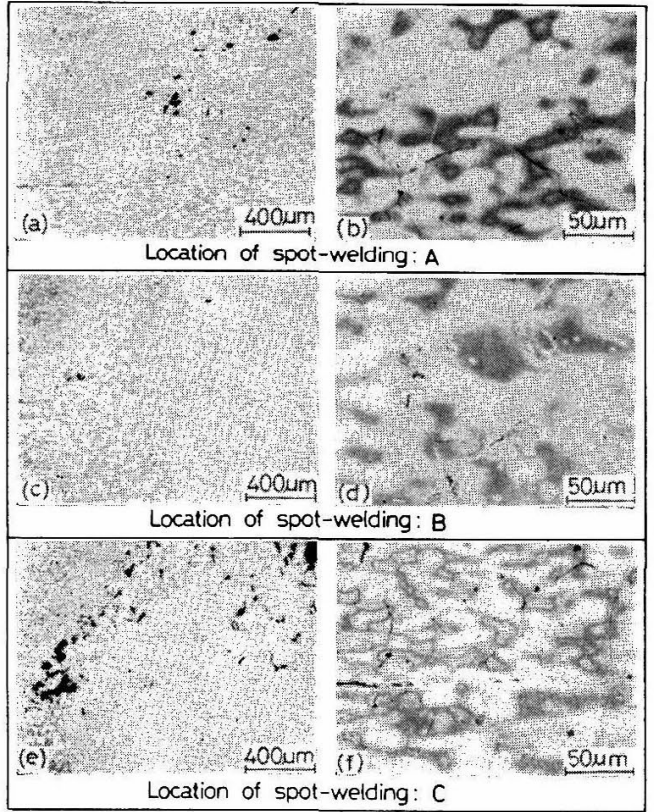

Fig. 9 Micro-structures of HAZ in spot-welded Mod. A 669 after immersed in 0.1 mass \% $\mathrm{NaCl}$ solution at $80^{\circ} \mathrm{C}$.

このように， $\mathbf{N}$ 添加鎆といえどもスポット溶接部にお いては $\alpha$ 単相部の生成に起因する耐食性劣化を生じる 場合のあることがわかるが，この現象は大ポット溶接の 順序と関連するものと考光られる。すなわち, 最初に溶 接したB部では $\alpha$ 単相部が生成し難く, 次いで溶接し た $\mathrm{A}$ 部及びC部では $\alpha$ 単相部が生じた理由としては，

(1) $\mathrm{A}$ 部及び $\mathrm{C}$ 部では拘束応力下で溶接が行われた

(2) B 部におけるA部，C 部溶接による熱影響の寄与
(3) 各溶接部に批る冷却速度の違いが挙げられる。 これらの内で(2)についてはB部が $\mathrm{A}, \mathrm{C}$ 部より数 $\mathrm{mm}$ 以上離れていることから, 短時間に $\gamma$ 相を安定化する程 の高温 (約 $1000^{\circ} \mathrm{C}$ 以上) に加熱されていないので可能 性は薄い。また, (3)の冷却速度の違いについては冷却速 度が大きくなる程 $\alpha$ 単相部を生じやすいのであるが, 両 端の $\mathrm{A}, \mathrm{C}$ 部がB部より冷却速度が著しく大きくなる状 況は考学難く, 従って可能性としては(1)の拘束応力下で の溶接に起因するとの推察が最も妥当と考光られる。

2 相ステンレス鋼を拘束応力下で溶接すると, $\alpha$ 単相 部を生じやすいことは既に梶山ら ${ }^{9}$ とよって指摘されて いるが，この点をさらに究明するため溶接熱サイクル再 現熱処理材の顕徽鏡組織に及ぼす引張応力付加の影響に ついて検討を行った。Fig. 10 は $1350^{\circ} \mathrm{C}$ に加熱後, 急冷 する溶接熱サイクル再現熱処理において, 冷却後の顕微 鏡組織に及ぼす熱処理時の拘束の影響を調べたもので, 䡛微鏡組織とともに温度及び付加応力の経時変化も示し ている。拘束応力の有無にかかわらず，A 669 に比べて Mod. A 669 の粒界に拈ける $\gamma$ 相の析出量の多くなるこ とがわかる。一方, A 669 (b) 及び Mod. A 669 (d) い ずれに扎いても溶接洔の応力付加によって $\gamma$ 相の析出 が抑制されることが明らかである。これは $\alpha \rightarrow \gamma の$ の相変 態に際し両者の結晶構造の差異により寸法収縮が起こ るが, 引張応力が付加されているとこの寸法収縮が抑制 される結果として $\alpha \rightarrow \gamma$ の相変態が抑制されることによ るものと考克られる。

\subsection{3 突合せ及び管端溶接部の顕微鏡組織}

一般に金属材料を溶接する場合, 拘束応力が付加され るのが通例であるので，上記の拘束応力下に和ける $\alpha$ 単
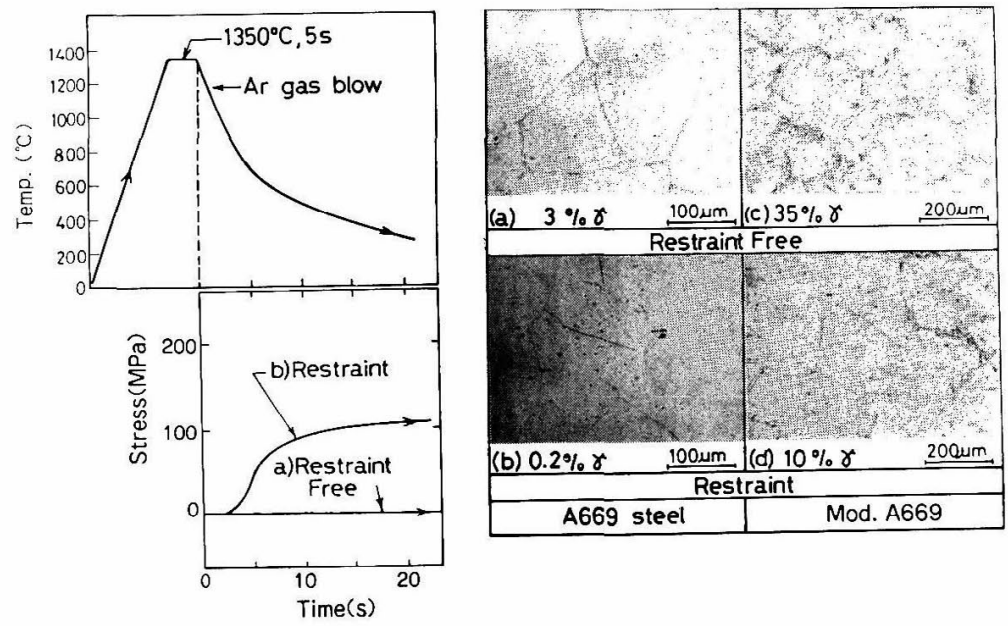

Fig. 10 Effect of restraint stress on micro-structures of duplex stainless steels during heattreatment to simulate the welding thermal cycle. 
相部生成の問題は重大であるが， $\alpha$ 単相部の生成は溶接 時に高温に加熱される溶融線のごく近傍で生じることか ら適切な組成の溶接棒を使用することによって $\alpha$ 単相 部生成の問題を回避することが可能であると考えられ る。そこで，筆者らはこの目的に合致するよう $0.01 C-$ $23 \mathrm{Cr}-7 \mathrm{Ni}-3 \mathrm{Mo}-0.14 \mathrm{~N}$ 系の TIG 溶接棒を試作 し, こ れを用いて拘束応力下で鋼板の突合せ溶接及び模擬管板 と管との管端溶接を行い, その溶接 HAZ の顕微鏡組織 を調査した。鋼板の突合せ溶接部の顕微鏡組織を観察す るとA 669 ではこのような溶接棒を用いても溶接 HAZ に $\alpha$ 単相部を生じるが, Mod. A 669 では耐食性の劣化 を防ぐのに十分な量の $\gamma$ 相が析出して拉り，良好な耐食 性を確認することができた。また，Mod．A669 の継目 無し鋼管について模擬管板との間で管端溶接を行い, 溶 接HAZ の顕微鏡組織観察及び EPMA 線分析を行った ところ, この場合にも耐食性の劣化を防止するのに十分 な量の $\gamma$ 相の析出が確認された。

このように，母材としてNを約 0.1 mass\% 添加した Mod. A 669 を使用し, 溶接棒として適切な組成の 2 相 ステンレス鋼を用いることにより, 耐食性の優れた健全 な溶接継手を得ることができることがわかった。

\section{4. 結 言}

$1.5 \mathrm{Si}-19 \mathrm{Cr}-5 \mathrm{Ni}-2.7 \mathrm{Mo}$ 系 2 相ステンレス 鋼の母材 及び溶接部の, 特に塩化物環境下における耐食性に及ぼ す $\mathbf{N}$ 添加の影響を検討した結果, 次の点が明らかとな った。

(1) $1.5 \mathrm{Si}-19 \mathrm{Cr}-5 \mathrm{Ni}-2.7 \mathrm{Mo}$ 系 2 相ステンレス鋼に約 0.1 mass\% の N を添加することにより, 塩化物環 境下に括ける耐陌間腐食性, 而 SCC 性並びに溶接 部の耐粒界腐食性が著しく改善される。

(2) $\mathbf{N}$ の添加によって酎食性が向上するのは, $\mathbf{N}$ が $\gamma$
相中に濃縮することによって $\alpha$ 相に比べて相対的 に Cr，Mo 含有量の低い $\gamma$ 相の耐食性が向上する ためと考兄られる。一方，溶接部に扣いてはNが 生成元素として作用し， $\alpha$ 単相域の生成を抑制する ことにより耐粒界腐食性を著しく向上させる。

(3) $\mathbf{N}$ 添加の 2 相ステンレス鋼とい光ども拘束応力 下で溶接すると， $\alpha$ 単相域を生成して粒界腐食を生 じる場合がある。しかしながら，母材としてN添加 鋼を使用し，溶接棒として $0.01 \mathrm{C}-23 \mathrm{Cr}-7 \mathrm{Ni}-3 \mathrm{Mo}$ $0.14 \mathrm{~N}$ 系の適切な組成のものを用いて溶接すること により, 溶接 HAZ の耐食性劣化を防止するのに十 分な量の $\gamma$ 相が析出した健全な溶接継手を得ること がでさる。

(Received June 15, 1988)

\section{文献}

1) S. Bernhardsson, R. Mellstrom and J. Oredsson: Corrosion/81, Paper No. 124 (April 1981).

2) N. D. Greene, Jr, W. D. France, Jr. and B. E. Wilde: Corrosion, 21, 275 (1965).

3）小若正倫，長野博夫，鈴木英次郎：鉄と鋼，65, 1953 (1979).

4) R. M. Kain: Mater. Perform., 23 [2] 24 (1984).

5) K. Fujiwara, H. Tomari, H. Hamada, T. Kadonaga and K. Wada: Proc. of The Third International Conference on Steel Rolling, 25-3 p. 621 (Sept. 1985).

6）泊里治夫, 藤原和雄：第 34 回腐食防食討論会予 稿集, p. 311 (1987 年 10 月).

7）増尾 誠, 小野 寛, 大橋延夫：防食技術, 29 [1] 3 (1980).

8) 小若正倫：日本金属学会会報, 17, 657 (1978).

9) 梶山裕久, 山上雅弘：腐食と対策事例集 (腐食防 食協会), p. 180 (1985). 